\author{
Prusov Dmitry, \\ Doctor of Technical Sciences, \\ Associate Professor, Senior Research Fellow, \\ Head of the Department of Territory Management, \\ Institute of Innovative Education of \\ Kyiv National University of Construction \\ and Architecture \\ ORCID 0000-0002-7322-6727 \\ Novikova Innola, \\ Doctor of Economical Sciences, \\ Associate Professor, \\ Head of the Department of Economics and \\ Management, \\ Institute of Innovative Education of \\ Kyiv National University of Construction \\ and Architecture \\ ORCID 0000-0002-1720-2798
}

\title{
OPEN INNOVATIONS: CROSS-CULTURAL FACTORS IN THE CONTEXT OF GLOBALIZATION
}

Purpose of the article is to identify and justify the need to implement cross-cultural factors in the development of innovations in Ukraine. Methodological basis of the research is the use of both general scientific and sociological methods. The theoretical and methodological basis of work is the system of general scientific and special methods, namely: historical-logical method - to study the evolution of economic thought regarding the definition of cross-cultural factors and their types; theoretical generalization - to determine the functions of innovation; systematization - to streamline approaches to the concepts of open innovations and cross-cultural factors. General scientific methods of systematization and generalization, the method of comparative analysis allowed to assess the influence of cross-cultural factors on the development of innovations in the conditions of globalization. Scientific novelty is to substantiate the necessity of expanding cross-cultural factors in assessing the innovation potential of both an individual region and Ukraine as a whole in the current conditions of globalization. Conclusions. In modern conditions, Ukraine needs to learn the experience of foreign countries, in particular, the United States of America. This is the country where such innovation companies as Hewlett Packard, Dell, Microsoft, Oracle, Google and many others first appeared in the garage or in a student dormitory room, and then grew into global leaders. If Ukraine in the future wants to be a country with the innovative economy, it should make it possible for students to create a company in the garage and in a few years enter into the world market. It is necessary to educate a new generation of innovation-oriented youth, for whom there will be no cross-cultural restrictions and barriers.

Keywords: culture, cross-cultural factors, innovation, open innovations, globalization.

Прусов Дмитро Едуардович, доктор технічних наук, доцент, старший науковий співробітник, завідувач кафредри управління територіями ВСП «Інститут інноваційної освіти Київського національного університету будівництва та архітектури»; Новикова Іннола Вікторівна, доктор економічних наук, доцент, завідувач кафредри економіки та менеджменту ВСП «Інститут інноваційної освіти Київського національного університету будівництва та архітектури»

Відкриті інновації: крос-культурні фактори в умовах глобалізації

Мета статті полягає у визначені та обґрунтуванні необхідності впровадження крос-культурних фракторів при розвитку інновацій в Україні. Методологічною основою дослідження $€$ використання як загальнонаукових, так і соціологічних методів. Теоретичним і методичним підґрунтям роботи є система загальнонаукових і спеціальних методів, а саме: історико-логічний метод - для дослідження еволюції економічної думки щодо визначення крос-культурних факторів та їх видів; теоретичного узагальнення - для визначення фрункцій інновацій; систематизації - для упорядкування підходів до трактувань поняття відкритих інновацій та крос-культурних фракторів. Загальнонаукові методи систематизації та узагальнення, метод порівняльного аналізу дозволили здійсни оцінку впливу крос-культуних фракторів на розвиток інновацій в умовах глобалізації. Наукова новизна полягає в обґрунтуванні необхідності розширення крос-культуних факторів при оцінці інноваційного потенціалу як окремого регіону, так й України в цілому в сучасних умовах глобалізації. Висновки. В сучасних умовах Україні потрібно вчитися досвіду зарубіжних країн, зокрема, США. Саме в цій країні з'явилися, спочатку в гаражі або кімнаті студентського гуртожитку, а потім і виросли в глобальних лідерів інноваційні компанії Hewlett Packard, Dell, Microsoft, Oracle, Google і багато інших. Якщо Україна в перспективі хоче бути країною з інноваційною економікою, в країні має стати можливим створення компанії студентами в гаражі і вихід ії на світовий ринок за кілька років. Необхідно виховувати нове покоління інноваційно орієнтованої молоді, для якої не будуть існувати крос-культурні обмеження та бар'єри.

Ключові слова: культура, крос-культурні фрактори, інновація, відкрити інновації, глобалізація.

Прусов Дмитрий Эдуардович, доктор технических наук, доцент, старший научный сотрудник, заведующий кафредрой управления территориями ОСП «Институт инновационного образования Киевского национального университета строительства и архитектуры»; Новикова Иннола Викторовна, доктор экономических наук, доцент, заведующий кафедрой экономики и менеджмента ОСП «Институт инновационного образования Киевского национального университета строительства и архитектуры»

Открытые инновации: кросс-культурные факторы в условиях глобализации

Цель статьи заключается в определении и обосновании необходимости внедрения кросс-культурных факторов при развитии инноваций в Украине.Методологической основой исследования является использование как общенаучных, так и социологических методов. Теоретическими и методическими основами работы является система общенаучных и специальных методов, а именно: историко-логический метод - для исследования эволюции экономической мысли по определению кросскультурных факторов и их видов; теоретического обобщения - для определения функций инноваций; систематизации - для упорядочения подходов к трактовкам понятия открытых инноваций и кросс-культурных факторов. Общенаучные методы систематизации и обобщения, метод сравнительного анализа позволили выполнить оценку влияния кросс-культуних факторов на развитие инноваций в условиях глобализации. Научная новизна заключается в обосновании необходимости расширения кросс-культуних факторов при оценке инновационного потенциала как отдельного региона, так и Украины в целом в современных условиях глобализации. Выводы В современных условиях Украины нужно перенимать опыт зарубежных стран, в частности США. Именно в этой стране появились сначала в гараже или комнате студенческого общежития, а затем выросли в 
глобальных лидеров такие инновационные компании, как Hewlett Packard, Dell, Microsoft, Oracle, Google и многие другие. Eсли Украина в перспективе хочет быть страной с инновационной экономикой, в стране должно стать возможным создание компании студентами в гараже и выход ее на мировой рынок через несколько лет. Необходимо воспитывать новое поколение инновационно ориентированной молодежи, для которой не будут существовать кросс-культурные ограничения и барьеры.

Ключевые слова: культура, кросс-культурные факторы, инновация, открыть инновации, глобализация

Formulation of the problem. Innovative economic development is considered today by many countries as one of the main ways of economic growth and competitiveness. The most attention in the issues of innovation is devoted to issues of innovation institutes; finances; state regulation of innovations, personnel, innovative technologies, intellectual property rights, while the culture of innovation often remains beyond discussion. Significant, but much less obvious (in comparison with technological) factor - national and business culture as a context of innovation - is almost not considered in modern literature. In our opinion, culture is the most important system-creating factor of the environment of innovation activity. Cross-cultural factors of innovation are becoming more significant in the context of the globalization of markets, industries and innovation processes.

In Ukraine by innovation traditionally they understood technical innovation. However, technical innovations are only part of the overall innovation process, and, as Ukrainian practice shows, it can not be successful outside the innovations of economic, cultural and political ones. It is no accident that Ukraine occupies only 42th place from 200 countries according to the Bloomberg Innovation Index 2017 [17].

The index is based on the overall indicator of the country's innovation (overall score) and contains an assessment of incoming, resource factors (innovation inputs) and the resulting (innovation performance) indicators of innovation. The challenges of technical innovation today go beyond the actual process of developing a new product, expanding the focus on issues such as business model, enterprise structure, value chain, patenting processes, channels, services, brand, customer experience [18]. Innovation, in the center of which there is a new product, today is impossible without marketing, informational, technological, organizational, sociocultural and financial innovations. The objective process of opening innovations in a globalized business environment implies the need for a wider approach to the consideration of innovations than is traditionally accepted in the Ukrainian scientific environment $[4,6]$.

Analysis of recent researches and publications. The theoretical analysis of the problem shows a wide range of scientific developments, the results of which serve as the basis for further research. The conceptual foundations of innovative processes are considered in the socio-philosophical context of civilizational changes, the rationale for a new paradigm of social development, the search for ways to overcome the crisis state (J. Allak, I. V. BestuzhevLada, A. A. Gerasimchuk, S. Hessen, F. Coombs, V. I. Zagvyazinsky, V. M. Rozin, M. I. Romanenko, B. Simon, P. Yu. Saukh, et al.). Historical and comparative analysis of the genesis of the theory and practice of innovative processes is presented in the works of O. Adamenko, I.P. Anosov, V.F. Zemlyanska, O.A. Maruschenko, A.V. Popova, N.V. Safonova and others. The justification of regularities, structure, content, models and conditions for the functioning and development of innovation processes is carried out from the standpoint of practical implementation of innovations, its effectiveness and viability (J. Basset, P. Drucker, O.V. Lorensov, I.P. Pidlasiy, O.M. Saranov, O.G. Khomeriki, A.V. Khutorsky, N.R. Yusufbekova, et al.). Domestic and foreign researchers of socio-cultural and socio-psychological aspects of innovations emphasize the analysis of personal characteristics of innovation activity subjects, peculiarities of perception and dissemination of innovations, formation of innovative style of thinking (V.L. Anoshkina, G.I. Gerasimov, V.P. Delia, L.V. llyukhin, S. Miller, S.V. Rezavanov, E. Rogers, P.A. Chebig, S.R. Yangolovsky, and others).

At the same time, the systematic, scientifically grounded technology of innovation implementation, which takes into account cross-cultural factors in both domestic and foreign literature is almost not represented. Practically no effective methods of expertise, selection and monitoring of innovations are applied. The issues of development of innovative potential remain insufficiently highlighted. The further development of mechanisms for the formation of innovative missions, strategies, environment for enterprises, which take into account cultural factors and peculiarities of the cross-cultural environment will require further development.

Purpose of the article is to identify and justify the need to implement cross-cultural factors in the development of innovations in Ukraine.

A presentation of the main research material. Integrated, multidisciplinary and interdisciplinary approach allows us to answer many questions of innovative perspective. Innovation is a new thing that has been made useful [12], with novelty and utility defined by the user, that is from the user's point of view. McKeown considers in general the process of innovation consisting of the following stages:

1. Idea $->2$. Collective idea $=$ insight $->3$. Insight application to practice $=$ invention $\rightarrow 4$. The use of the invention $=$ innovation.

In the innovation process emit usually two types of innovation - open and closed. In the process of closed innovation there is one participant. In the process of open innovation, there are several participants, for example $A$, $\mathrm{B}, \mathrm{C}, \mathrm{D}$ (see Figure 1), each of which is a person or group (organization), possibly from different countries. 
Fig. 1. Scheme of processes for closed and open innovation

\begin{tabular}{|l|c|c|c|c|c|c|}
\hline \multicolumn{1}{|c|}{ Participants } & $\begin{array}{c}\text { Closed } \\
\text { Innovation }\end{array}$ & & \multicolumn{4}{c|}{$\begin{array}{c}\text { Open } \\
\text { Innovation }\end{array}$} \\
\hline Stages & $A$ & & $A$ & $B$ & $C$ & \\
\hline Idea & $X$ & & $X$ & $X$ & & \\
\hline Collective idea = insight & $X$ & & & & $X$ & \\
\hline $\begin{array}{l}\text { Insight applica-tion to } \\
\text { practice = invention }\end{array}$ & $X$ & & & & & $X$ \\
\hline $\begin{array}{l}\text { The use of the invention }= \\
\text { innovation }\end{array}$ & $X$ & & & & & \\
\hline
\end{tabular}

The concept of open innovation relies on external participants as sources of ideas and means of commercialization of ideas [12].

Open innovation can be seen as a phenomenon that exists in a highly developed civilized market relations. The open innovation processes involve the free and voluntary interest of the interaction of many independent participants (both individuals and organizations) in a highly competitive and dynamically developing market environment. Open (in comparison with closed) innovations and processes are more demanding to the quality of economic, scientific, political, legal institutes, forming the environment of generation, management and use of innovations. In the context of global markets and industries (electronics, pharmaceuticals, telecommunications, automotive and aircraft engineering, food industry, software and others), open innovation cross borders between countries and regions. It is clear that the gap between innovative environment of Ukraine and the countries innovative leaders prevents the formation of transnational innovation chains, pushing our country to the periphery of a highly competitive innovation field.

The open type of innovation has developed in parallel with the globalization of economic processes and markets, the development of outsourcing in the research area, the more active inclusion of consumers in the innovation process and the further commercialization of technologies outside the companies, where innovation was carried out or applied for the first time. The use of open innovation methods depends on the effectiveness of the socalled intermediary markets for ideas and technologies. The company becomes a system integrator of internal and external technologies, for example, Apple integrates the software of external developers for the iPhone smartphone [3, p. 73]. The discovery of a product for external innovators (in particular Intel's Intel Inside strategy) transforms it into a platform, on which other market players build their decisions.

The opening of business models of innovation is due to such objective factors as globalization of markets and global competition, shortening the product life cycle and rising cost of time, increasing the complexity of new technologies (and therefore costs and risks), the development of markets for technological, personnel and financial decisions. Open innovation means openness of companies to collaborate around the world, as shown, in particular, by Procter \& Gamble, Hewlett Packard, LG. Globalization of markets, information environment and business processes creates the preconditions for the growth of the involvement of Ukrainian participants in transnational innovation processes and global networks for the creation of new goods and services [5].

The development, creation and distribution, and the use of many goods in the markets today is an international process. Finished goods cross the border and come to foreign markets, almost without changing their physical form. However, products containing implicit components, including services, are more sensitive to crosscultural barriers due to the persistence of cultural differences between countries and regions of the world. Cultural component of business and markets (ethics, emotions, motivation, cultural values) refers to "soft" factors, in contrast to "hard" factors - equipment, materials, components. "Soft" factors are difficult to measure, assess because of their implicit nature, they are difficult to manage, but they are becoming increasingly important for the functioning of a modern economy and for its development and innovation.

Managing innovations, and open innovations even more, is largely information process. It is a process of finding, collecting, processing and disseminating information in a global, the worldwide environment. Crossing the innovation chains of the country's borders involves overcoming cross-cultural barriers at least in the field of business communications, that is, the exchange of business information, as well as in the field of marketing communications. Business communications affect such essential components of open innovation as negotiations (formal and informal), correspondence, exhibitions and forums, conferences, agreements, current working interaction of participants, public relations and advertising, publications in mass media and specialized publications, sales promotion and more.

What prevents Ukraine from taking leadership positions in the innovation sector? A number of researchers talk about the role of cultural barriers for the innovation of nations. An American researcher, L. Harrison, who worked with the US AID mission in Central America and the Caribbean in 1962-1982, revealed in his daily work that poverty and injustice are rooted in the cultural values of the region [8, 9]. He wrote that "some religions and cultures are better than others, promote personal responsibility, education, entrepreneurship and trust - all the values that shape political and economic development" $[15,16]$. When it comes to democracy, prosperity and the law, Protestant communities - above all, the northern countries - Denmark, Finland, Iceland, Norway and Sweden - usually outnumber Catholic nations, especially Latin America. Confucian societies such as Japan, Singapore, South Korea, Taiwan, and today China, transform economic growth on a global scale. Islamic countries, even those with oil, are 
not developing sufficiently [8]. These ideas are partially supported by ratings, in particular by the global innovation index [2, p.25], where in the first twenty innovation countries there is no country from the Muslim world.

The results of Harrison's five-year research, - An educated policy can, over time (throughout the life of a generation), produce cultural change - which in turn will lead to political pluralism and economic development. The most important change tools are mentioned following:

1. Education, instilling democratic and entrepreneurial values.

2. Improving the upbringing of children.

3. Religious reform.

4. Development assistance aimed at cultural change.

Among the cultural factors of technological progress, British researcher G. Gelade calls such as open intellectual environment, intellectual autonomy and social equality [7]. An American researcher, S. Shane, noted that the adoption of uncertainty (both readiness for risk and change), individualism (as autonomy, independence and freedom), as well as the absence of a power distance (as the antipode of hierarchy and authoritarianism), were associated with the high level of nation's innovation in the period 1980s years. According to American researcher T. Friedman, the country's development is associated with such factors of culture as openness to foreign ideas, solidarity of the nation, readiness to cooperate with others, as well as the degree, at which the elite feels concern about the state of the masses [6]. Significant value of American society is such as the right to individuality, the right not to be like everyone and the right to be different. In this right, as well as in the recognition of the right of environmental reality to diversity - in looks, tastes, worldview, clothing and lifestyle there is the key to change, innovation and progress. Because the innovator is a person (or group), who does not that and not like everyone, he plays not by rules and often contrary to them. And in open innovation, the situation is even more serious - there are several such "others". According to the American scientist L. Harrison, a specialist in the field of culture as a factor of progress, the parameters of the comparison of crops can be divided by four groups:

1. A look at the world.

2. Values and virtues.

3. Economic behavior.

4. Social behavior.

The innovative environment in the age of globalization and open innovation goes beyond research and production centers, it permeates all the institutes of modern society and it is market-based in essence. Since open innovation, marketing and consumers today are closely related concepts, attention should be paid to interpreting culture from the point of view of marketing and consumer control problems. Culture is a complex that includes knowledge, faith, art, law, morals, customs, and any other abilities and skills that a person acquires as a member of society. Culture is a set of values, ideas, subjects of human labor and other meaningful symbols that help people, as members of society, communicate, interpret, and evaluate $[1, p .76]$. Culture includes both abstract and material (substantiated) elements. Abstract elements are values, relationships, ideas. Material components are tools, books, computers, buildings and facilities, as well as specific products such as car or airliner of a particular brand and model or software systems. All components of culture are interconnected.

The relationship of culture, the level of well-being of society and the quality of social institutions is also noted by one of the most prominent American researchers in the field of marketing and consumer behavior, J. Mowen [13, p. 702]. Mowen includes in the concept of a society's culture three sets of factors, the measurement of which forms a model of culture - a three-dimensional matrix:

1. A set of cultural values (for the USA - individualism, achievement, informality, equality, progress, materialism).

2. Material environment (economic development, geographic characteristics, natural resources, technical / scientific level).

3. Institutional / social environment (legal, political, business, religious, subcultures).

Cross-cultural aspects of business communications, public relations, partners, consumers in global markets for open innovation cover a variety of issues, from philosophical to everyday reality - space, time, etiquette, gestures, symbols, friendship, honor, justice, law, harmony. Cultural barriers - if viewed outside the purely humanitarian sphere - significantly affect the spread of innovation, Ukraine's integration into global innovation processes.

In countries - innovative leaders - cultural factors of business and management are the focus of attention of schools, universities, campaigns and government structures. At American universities there are courses in crosscultural management and business ethics (focusing on the global business space). Employees of global companies are trained in cross-cultural competency programs. Business-oriented communications aimed at international audiences are tested in terms of cross-cultural adequacy based on the criteria of target audiences, goals, sources, channels, coding systems, interference and feedback $[10,11]$.

To enhance the wide participation of Ukrainian business in open innovation, in terms of overcoming the nation's cross-cultural barrier, it seems advisable:

1. Growth of the creative component in Ukrainian education (the choice of a large proportion of courses and subjects for students) to strengthen the humanitarian component of education. Humanization of education, increasing attention to humanitarian technologies - the development of society and social processes. The success of many corporations is bound not so much by people with a quantitative type of intelligence, but by the interaction of leadership teams of people in the technical and humanitarian mindset, as shown by the example of Apple, Procter \& Gamble, Hewlett Packard and other successful global companies [14, p. 80]. In Ukraine, for many decades 
education has been focused on people with technical mindset that weakens the creative environment and part of the innovation process and its effectiveness as a whole. To capture the cultural barrier of innovation in the global environment, modern humanitarian training should be based not so much on the traditions of the past, but on the modern world experience of the leaders of innovative development.

2. Intensification of scientific research in the field of cross-cultural factors of economic growth and development of innovative economy.

3. Internationalization of education and the scientific sphere (business is internationalized by the problems of survival). This requires the study of a foreign language (and, accordingly, the culture of developed countries innovative leaders) starting from primary school. There is a need for increased openness for external interactions between education and science systems. An open type innovator who capable working in global innovation networks must be formed, accordingly, by a more global-oriented, world-class education and science system for the outside world.

4. Promotion of innovations and innovative values in the mass-media. While the image of a successful innovator is not the dream of millions Ukrainian students and their parents, the innovative rise of the country's economy is less likely and more complicated.

CONCLUSIONS. In modern conditions, Ukraine needs to learn the experience of foreign countries, in particular, the United States. This is the country where such innovation companies as Hewlett Packard, Dell, Microsoft, Oracle, Google and many others first appeared in the garage or in a student dormitory room, and then grew into global leaders. If Ukraine in the future wants to be a country with the innovative economy, it should make it possible for students to create a company in the garage and in a few years enter into the world market. It is necessary to educate a new generation of innovation-oriented youth, for whom there will be no cross-cultural restrictions and barriers.

\section{תimepamypa}

1. Алёшина И. В. Поведение потребителей. М.: Экономистъ, 2006. 525 с.

2. Andrew J. P., DeRocco E. S., Taylor A. The Innovation Imperative in Manufacturing. How the United States Can Restore Its Edge. BCG, MI, NAM. March, 2009. 32 pp.

3. Boudreau K. J. and Lakhani K. R. How to Manage Outside Innovation - MIT Sloan Management Review, Summer, 2009, Vol. 50, N 4, pp - 69-75.

4. Chesbrough H. Open Business Models. Cambridge, Massachusetts: Harvard Business Press, 2006. 256 pp.

5. Friedman T. L. The World is Flat: A Brief History of the Twenty First Century. Findaway World, 2006. 784 p.

6. Gelade G. A. IQ, cultural values, and the technological achievement of nations. - Intelligence. Volume 36, Issue 6, NovemberDecember 2008, pp. 711-718.

7. Harrison L. E. (2006 a) The Central Liberal Truth: How Politics Can Change a Culture and Save It from Itself. Oxford University Press, 2006. $272 \mathrm{p}$.

8. Harrison L. E. (2006 b) Hearts, Minds and Schools.- Washington Post, Sunday, December 16.2006; B 03.

9. Lawrence E. Harrison. The Central Liberal Truth. Oxford University Press, 2006. 288 p.

10. McKeown, Max (2008). The Truth About Innovation. London, UK: Prentice Hall. 249 p.

11. Mowen J. C. Consumer Behavior. 4-th ed. Macmillan Publishing Co., 1995. 862 pp.

12. Rigby D. K., Gruver K., and Allen J. Innovations in Turbulent Times. Harvard Business Review, June 2009, pp. 79-86.

13. Shane S. Cultural influences on national rates of innovation. - Journal of Business Venturing. Volume 8, Issue 1, January 1993, P. 59-73.

14. Schmemann S. Yegor Gaidar, the Man Who Killed the Command Economy. The New York Times, December 22, 2009.

15. Самые инновационные экономики мира: в топе скандинавские страны, лидер - Южная Корея URL: http://theworldonly.org/rejtinginnovatsionnyh-ekonomik/

16. Топ-100 найбільших компаній світу за ринковою капіталізацією 2014 URL: http://www.pwc.com/ua/uk/survey/2014/all/globaltop-1002014.html

17. Федулова Л.І. Сьомий технологічний уклад: міфи, реальність та перспективи. Економічна теорія. 2012. № 1 (8). С. 7-18.

\section{References}

1. Aleshina I.V (2006) Consumer behavior. M., The Economist [in Russian].

2. Andrew J. P., DeRocco E. S., Taylor A. (2009) The Innovation Imperative in Manufacturing. How the United States Can Restore Its Edge. BCG, MI, NAM. March [in English].

3. Boudreau K. J. and Lakhani K. R. (2009) How to Manage Outside Innovation - MIT Sloan Management Review, Summer, 50, 4, 69-75 [in English].

4. Chesbrough H. (2006). Open Business Models. Cambridge, Massachusetts: Harvard Business Press [in English].

5. Friedman, T. L. (2006) The World is Flat: A Brief History of the Twenty First Century. Findaway World [in English].

6. Gelade, G.A. (2008) IQ, cultural values, and the technological achievement of nations. Intelligence, 36, 6, Nov.-Dec., 711-718 [in English].

7. Harrison, L. E. (2006 a) The Central Liberal Truth: How Politics Can Change a Culture and Save It from Itself. Oxford University Press, [in English].

8. Harrison, L. E. (2006 b). Hearts, Minds and Schools. - Washington Post, Sunday, December 16. B 03 [in English].

9. Lawrence, E. Harrison. (2006). The Central Liberal Truth. Oxford University Press [in English].

10. McKeown, Max (2008). The Truth About Innovation. London, UK: Prentice Hall [in English].

11. Mowen, J. C. (1995) Consumer Behavior. 4-th ed. Macmillan Publishing Co. [in English].

12. Rigby D. K., Gruver K., and Allen J. (2009) Innovations in Turbulent Times. - Harvard Business Review, June, $79-86$ [in English].

13. Shane, S. (1993) Cultural influences on national rates of innovation. - Journal of Business Venturing, 8, 1, January, $59-73$ [in English].

14. Schmemann, S. (2009). Yegor Gaidar, the Man Who Killed the Command Economy. The New York Times, December 22 [in English].

15. The most innovative economies in the world: the top of the Scandinavian countries, the leader - South Korea. URL: http://theworldonly.org/rejtinginnovatsionnyh-ekonomik/ [in Ukainian]

16. Top 100 largest market capitalization companies in 2014. Retrieved from: http://www.pwc.com/ua/uk/survey/2014/all/globaltop-1002014.html [in Ukainian]

17. Fedulova, L.I. (2012). Seventh Technological Structure: Myths, Reality and Perspectives. Economic Theory,1 (8), 7-18 [in Ukainian]. 